CLINICAL STUDY

\title{
Fifteen years of GH replacement improves body composition and cardiovascular risk factors
}

\author{
Mariam Elbornsson $^{1,2}$, Galina Götherström ${ }^{1,2}$, Ingvar Bosæus ${ }^{3}$, Bengt-Åke Bengtsson ${ }^{1,2}$, \\ Gudmundur Johannsson ${ }^{1,2}$ and Johan Svensson ${ }^{1,2}$ \\ ${ }^{1}$ Department of Endocrinology, Sahlgrenska University Hospital, Gröna Stråket 8, SE-413 45 Göteborg, Sweden, ${ }^{2}$ Institute of Medicine, Sahlgrenska \\ Academy, University of Gothenburg, SE-413 45 Göteborg, Sweden and ${ }^{3}$ Department of Clinical Nutrition, Sahlgrenska University Hospital, SE-413 45 \\ Göteborg, Sweden \\ (Correspondence should be addressed to M Elbornsson at Department of Endocrinology, Sahlgrenska University Hospital; \\ Email: mariam.elbornsson@medic.gu.se)
}

\begin{abstract}
Objective: Few studies have determined the effects of more than 5-10 years of GH replacement in adults on body composition and cardiovascular risk factors.

Design/patients: In this prospective, single-center, open-label study, the effects of 15 years of GH replacement on body composition and cardiovascular risk factors were determined in 156 hypopituitary adults (93 men) with adult-onset GH deficiency (GHD). Mean age was 50.5 (range 22-74) years at study start. Body composition was measured using dual-energy X-ray absorptiometry. Results: The mean initial GH dose of 0.55 (s.e.M. 0.03) mg/day was gradually lowered to $0.40(0.01)$ $\mathrm{mg} /$ day after 15 years. The mean serum IGF1 SDS increased from $-1.53(0.10)$ at baseline to 0.74 (0.13) at study end $(P<0.001$ vs baseline). Lean soft tissue (LST) increased to $3 \%$ above the baseline level at study end $(P<0.001)$. After a 9\% decrease during the first year of treatment $(P<0.001$ vs baseline), body fat (BF) started to increase and had returned to the baseline level after 15 years. Serum levels of total cholesterol and LDL-cholesterol decreased and serum HDL-cholesterol level increased. Fasting plasma glucose increased from $4.4(0.1)$ at baseline to $4.8(0.1) \mathrm{mmol} / \mathrm{l}$ at study end $(P<0.001)$. However, blood HbA1c decreased from $5.0(0.1)$ to $4.6(0.1) \%(P<0.001)$.

Conclusions: Fifteen-year GH replacement in GHD adults induced a transient decrease in BF and sustained improvements of LST and serum lipid profile. Fasting plasma glucose increased whereas blood $\mathrm{HbA1c}$ was reduced.
\end{abstract}

European Journal of Endocrinology 168 745-753

\section{Introduction}

GH-deficient (GHD) adults have abnormal body composition (1), impaired lipid profile (1), decreased insulin sensitivity (1), and increased cardiovascular morbidity and mortality $(2,3)$. Within the first year of treatment, GH replacement therapy normalizes the alterations in body composition through a reduction in body fat (BF) and an increase in lean mass $(4,5,6)$. The increase in lean mass is sustained for up to 10 years during $\mathrm{GH}$ replacement $(7,8)$. However, BF gradually returns toward baseline values during prolonged GH replacement $(7,8)$, which could possibly be an effect of the normal aging of the patients (8).

GH replacement improves serum lipid profile with a decrease in serum LDL-cholesterol (LDL-C) and, in most studies, an increase in serum HDL-cholesterol (HDL-C) $(7,8,9,10)$. Depending on the duration of $\mathrm{GH}$ replacement and the dose of $\mathrm{GH}$ administered, serum triglyceride (TG) level may be increased, unchanged, or decreased $(7,8,9,10)$.
The effect of $\mathrm{GH}$ on glucose homeostasis is still controversial. Both unchanged (4) and increased (8, 9, $10,11)$ fasting plasma glucose concentrations have been observed. The acute insulin antagonist effect of GH could be one mechanism underlying the deterioration of glucose homeostasis seen during the first months of GH replacement (12). During long-term GH replacement, insulin sensitivity has either continued to be decreased $(4,13)$, returned to the baseline level $(14)$, or increased compared with baseline (15). A fixed low GH dose of $0.1 \mathrm{mg}$ increased insulin sensitivity compared with unchanged insulin sensitivity with a standard dose aiming at normalizing insulin-like growth factor 1 (IGF1) (16). In one study, 7 years of GH replacement provided protection against the normal age-related decline in insulin sensitivity (12), possibly as a result of the improvements in body composition (12).

The effects of GH replacement on body composition and cardiovascular risk factors after more than 10 years of treatment have not been previously studied. However, we demonstrated that 15 years of $\mathrm{GH}$ replacement 
induced sustained increases in total body and lumbar (L2-L4) spine bone mineral content (BMC) and bone mineral density (BMD), whereas femur neck BMC and BMD increased up to 7 years of GH replacement and then decreased toward baseline levels (17). As GHD is a chronic disease and GH replacement may continue over decades, long-term studies are of importance. The aim of this prospective, single-center, open-label study was to evaluate the effects of 15 years of $\mathrm{GH}$ replacement in 156 hypopituitary adults on body composition and cardiovascular risk factors.

\section{Materials and methods}

\section{Patients}

In this study, 156 consecutive GHD adults (93 men) with a mean age of 50.5 (range 22-74) years were included in 1990-1996. All patients had adult-onset pituitary disease and all had known pituitary disease or other anterior pituitary hormonal deficiencies. The pituitary deficiency was mainly caused by pituitary tumors and/or their treatment (Tables 1 and 2). The patients had been treated with pituitary surgery $(n=73)$, surgery and radiotherapy $(n=47)$, radiotherapy alone $(n=13)$, and no treatment $(n=23)$.

Most patients had multiple anterior pituitary hormonal deficiencies (Tables 1 and 2). Possibly due to late effects of radiotherapy, several patients had more pituitary hormonal deficiencies at study end compared with baseline (Tables 1 and 2). In 145 of the patients, the diagnosis of GHD was based on a peak $\mathrm{GH}<3 \mu \mathrm{g} / \mathrm{l}$ during a stimulation test (insulin $(n=137)$, GHRH $(n=5)$, and glucagon $(n=3))$. In nine patients, the diagnosis was based on a 24-h GH profile (sampling every $30 \mathrm{~min}$ ). In two patients, both having a known anterior pituitary disease and three additional hormonal deficiencies, the diagnosis was based on a low serum

Table 1 Causes of pituitary deficiency in the study population of 156 (93 men) adults with adult-onset GHD.

\begin{tabular}{lrrr}
\hline & $\begin{array}{c}\text { Men } \\
(n)\end{array}$ & $\begin{array}{c}\text { Women } \\
(n)\end{array}$ & $\begin{array}{c}\text { Total } \\
(n)\end{array}$ \\
\hline Non-secreting pituitary adenoma & 53 & 22 & 75 \\
Secreting pituitary adenoma & 15 & 19 & 34 \\
Craniopharyngioma & 9 & 7 & 16 \\
Empty sella & 4 & 3 & 7 \\
Sheehan's syndrome & 0 & 3 & 3 \\
Idiopathic & 2 & 3 & 5 \\
Pituitary apoplexia & 2 & 1 & 3 \\
Sarcoidosis & 2 & 2 & 4 \\
Traumatic brain injury & 1 & 1 & 2 \\
Other pathology $^{2}$ & 5 & 2 & 7 \\
Total & 93 & 63 & 156
\end{tabular}

GHD, GH deficiency.

${ }^{\mathrm{a} C}$ Contains one patient with a meningioma, one with histiocytosis $\mathrm{X}$, one with a cholesteatoma, one with an ependymoma, one with a dysgerminoma, one with a granular cell tumor, and one with APS2.
IGF1 level. When required, patients received adequate and stable therapy with glucocorticoids, thyroid hormone, and desmopressin. All the testosteronedeficient men received testosterone therapy. However, at baseline, $60 \%$ (34 out of 57) of the estrogen-deficient women received estrogen replacement therapy.

Twenty-one of the patients died during the study period (cerebral infarction $(n=3)$, myocardial infarction $(n=3)$, pneumonia $(n=3)$, sudden death of unknown cause $(n=3)$, renal cancer $(n=1)$, subarachnoid hemorrhage $(n=1)$, chronic obstructive pulmonary disease $(n=1)$, perimyocarditis $(n=1)$, pulmonary embolism $(n=1)$, coronary artery disease $(n=1)$, sepsis $(n=1)$, dementia $(n=1)$, and cortisol deficiency during gastroenteritis $(n=1))$. Thirteen $(62 \%)$ of the patients who died had previously been treated with pituitary irradiation therapy. Eighteen patients discontinued GH replacement (lack of compliance $(n=9)$, old age $(n=3)$, colon cancer $(n=1)$, stroke $(n=1)$, epilepsy after stroke $(n=1)$, pulmonary cancer $(n=2)$, and chronic lymphocytic leukemia $(n=1)$ ). Eight patients were lost to follow-up because they moved to other cities or abroad. Thus, 109 of the 156 patients completed the 15 years of $\mathrm{GH}$ replacement. The total number of patient years was 1971. All patients were, however, retained in the statistical analysis according to the intention-to-treat approach used.

For patients receiving medical therapy for hypertension, hypercholesterolemia, or diabetes, the last value before treatment (measures of blood pressure, lipid profile, or glucose metabolism) was carried forward in the statistical analysis.

\section{Study protocol}

This is an ongoing, prospective, open-label treatment trial. The first 64 patients initially received a weightbased $\mathrm{GH}$ dose of $11.9 \mu \mathrm{g} / \mathrm{kg}$ per day $(0.25 \mathrm{IU} / \mathrm{kg}$ per week). During the first years of treatment, the $\mathrm{GH}$ dose was gradually lowered and individualized when the weight-based dose regimen was abandoned. In the remaining 92 patients, the dose of $\mathrm{GH}$ was individualized from the beginning, with the aim of normalizing serum IGF1 concentration and body composition in each patient (18).

At baseline, and after each year of $\mathrm{GH}$ replacement until 5 years, and then after $7,10,12$, and 15 years, physical and laboratory examinations were performed including measurements of body composition. Dose titration and safety monitoring were performed every third month during the first year and every sixth month thereafter. Body weight was measured in the morning to the nearest $0.1 \mathrm{~kg}$, and body height was measured to the nearest $0.01 \mathrm{~m}$. BMI was calculated as the weight in kilograms divided by the height in meters squared. No effort was made to influence the patients' physical activity level during the study period. 
Table 2 Number of pituitary deficiencies at baseline and after 15 years of GH replacement (study end) in the study population of 156 (93 men) adults with adult-onset GHD.

\begin{tabular}{|c|c|c|c|c|c|c|}
\hline \multirow[b]{2}{*}{ Type of deficiency } & \multicolumn{3}{|c|}{ Baseline $(n)$} & \multicolumn{3}{|c|}{ Study end $(n)$} \\
\hline & Men & Women & Total & Men & Women & Total \\
\hline Isolated GHD & 11 & 2 & 13 & 4 & 1 & 5 \\
\hline 1 Additional deficiency & 10 & 10 & 20 & 3 & 7 & 10 \\
\hline 2 Additional deficiencies & 12 & 9 & 21 & 17 & 7 & 24 \\
\hline 3 Additional deficiencies & 60 & 42 & 102 & 69 & 48 & 117 \\
\hline Diabetes insipidus & 25 & 17 & 42 & 26 & 20 & 46 \\
\hline
\end{tabular}

GHD, GH deficiency.

\section{Ethical considerations}

Informed consent was obtained from all patients. The study was approved by the Regional Ethics Review Board at the University of Gothenburg and the Swedish Medical Products Agency (Uppsala, Sweden).

\section{Body composition}

Dual-energy X-ray absorptiometry (DXA) was used to measure lean soft tissue (LST), BF, and trunk fat (TF) as described previously (19). Appendicular LST (ALST) was calculated as the sum of LST in the arms and legs and used to estimate skeletal muscle mass (20). From the start of the study until the end of 1999, a LUNAR DPX-L scanner was used (Scanex, Helsingborg, Sweden). Software versions were changed several times (from 1.1 to lastly 1.35), version 1.33 being used during the major part of this period of the study. In-house precision error on the scanner used, as determined from duplicate examinations in ten healthy subjects, was $1.5 \%$ for LST.

From January 2000, a LUNAR Prodigy scanner (Scanex) was used. Software versions were upgraded several times during data collection, from version 5.70 to 8.10. The precision of the scanner was estimated from repeated measurements on different days in 30 subjects with coefficient of variation (CV) of LST being $1.1 \%$. Before the change of scanner in the end of 1999, the old and new DXA machines were compared by measurements on the same day on both machines in 30 subjects. No significant differences in body composition parameters were found.

\section{Biochemical analysis}

All biochemical analyses were performed at the Sahlgrenska University Hospital Laboratory, which is accredited according to international standards by the Swedish Board for Accreditation and Conformity Assessment (Swedac). Serum IGF1 concentration, until June 2004, was determined by a hydrochloric acid-ethanol extraction RIA (Nichols Institute Diagnostics, San Juan Capistrano, CA, USA). Interassay and intra-assay CV were 5.4 and $6.9 \%$ respectively at a mean serum IGF1 level of $126 \mu \mathrm{g} / \mathrm{l}$ and 4.6 and $4.7 \%$ respectively at mean serum IGF1 level of $327 \mu \mathrm{g} / \mathrm{l}$. From
June 2004 to August 2006, serum IGF1 concentration was determined using a chemiluminescence immunoassay (Nichols Advantage; Nichols Institute Diagnostics) (21). From September 2006, serum IGF1 level was determined using an automated chemiluminescent assay system (IMMULITE 2500, Diagnostic Products Corp., Los Angeles, CA, USA). The WHO NIBSC 1st IRR $87 / 518$ standard was used for calibration throughout the study period. The individual serum IGF1 values were compared with age- and sex-adjusted values obtained from a reference population (22), and the individual IGF1 SDS were then calculated (23).

Serum levels of total cholesterol (TC), HDL-C, and TGs were measured using enzymatic methods (8). LDL-C was calculated according to Friedewald's formula adjusted to SI units (24). Serum LDL-C was excluded in patients with serum TG $>4.3 \mathrm{mmol} / \mathrm{l}$. Blood glucose was measured with the glucose-6-phosphate dehydrogenase method (Kebo Lab, Stockholm, Sweden) until April 1998. From May 1998, plasma glucose was measured with a hexokinase method (Roche Diagnostics Scandinavia AB). All blood glucose values obtained before May 1998 were converted to plasma glucose values using a multiplication factor of 1.11. Blood HbAlc was determined by HPLC (Waters, Millipore AB, Solna, Sweden).

\section{Statistical analysis}

The descriptive statistical results are presented as the mean and s.e.m. For all variables, within-group differences were calculated using a repeated-measures ANOVA, with all data obtained from all time points, and with time as the independent variable. Post hoc analysis was performed using Student-Newman-Keuls test. Gender differences and differences between women receiving or not receiving estrogen replacement were calculated by a two-way ANOVA with gender or estrogen treatment as the independent variables. In order to eliminate the baseline differences, data were transformed into percent change or change from baseline before the between-group analyses.

All analyses were performed according to the intention-to-treat principle (using the carry forward principle). A two-tailed $P<0.05$ was considered significant. 


\section{Results}

\section{GH dose, serum IGF1, and BMI}

The dose of GH prescribed at the baseline visit was 0.55 $(0.03) \mathrm{mg} /$ day (Table 3$)$. The dose was then gradually reduced to $0.40(0.01) \mathrm{mg} /$ day at study end. Mean IGF1 SDS (adjustment for age and gender) was above the normal range during the first 3 years, but after that, it was within the normal range $( \pm 2$ S.D.). There was no change in height or weight whereas BMI increased from $27.7 \mathrm{~kg} / \mathrm{m}^{2}$ at baseline to $28.3 \mathrm{~kg} / \mathrm{m}^{2}$ at study end $(P<0.01)$. Systolic blood pressure increased whereas diastolic blood pressure was unchanged.

\section{DXA body composition}

LST increased by 3\% during the first year of $\mathrm{GH}$ replacement and was then stable throughout the study period (Fig. 1). Also, LST expressed as a percentage of body weight increased significantly $(P<0.001$; Table 4). ALST increased up to 10 years of $\mathrm{GH}$ replacement $(P<0.05)$ and then decreased toward the baseline value.

Total BF decreased by 9\% during the first year of treatment $(P<0.001)$, was still below the baseline level after 10 years $(P<0.01)$, but had returned to the baseline level at study end (Fig. 1). However, total BF expressed as a percentage of body weight was still significantly below the baseline level at study end $(P<0.01$; Table 4). TF decreased by $10 \%$ during the first year $(P<0.001)$, stayed below the baseline level up to 5 years $(P<0.001)$, and then increased to $6 \%$ above the baseline level after 15 years $(P<0.001$; Fig. 1$)$.

\section{Lipids and glucose}

There were sustained decreases in serum levels of TC and LDL-C (both $P<0.001$ vs baseline; Table 4). Serum HDL-C concentration increased $(P<0.001$ vs baseline).
There was no change in serum TG level. Fasting plasma glucose level increased throughout the study period $(P<0.001)$, whereas blood HbA1c level decreased $(P<0.001)$.

\section{Diabetes mellitus}

Four patients (two men) had diabetes mellitus (DM) type 2 at baseline. During the study period, 12 patients (nine men) were diagnosed and treated for DM type 2 (within 5 years, $n=2$; after $5-10$ years, $n=7$; after $>10$ years, $n=3)$. Five $(42 \%)$ of these 12 patients had previously been treated with pituitary irradiation therapy. At baseline, the patients who later developed DM type 2 had higher body weight (96.4 vs $81.3 \mathrm{~kg} ; P<0.01)$, BF $(35.3$ vs $26.6 \mathrm{~kg} ; P<0.01)$, TF $(18.1$ vs $14.1 \mathrm{~kg}$; $P<0.01$ ), fasting plasma glucose $(5.1 \mathrm{vs} 4.4 \mathrm{mmol} / \mathrm{l}$; $P<0.001)$, and serum TG level $(2.3$ vs $1.7 \mathrm{mmol} / \mathrm{l}$; $P<0.05)$.

\section{Gender differences}

Except for the first year of treatment, women received a higher GH dose than men $(P<0.001)$. The mean initial GH dose was $0.59(0.04) \mathrm{mg} /$ day in men and 0.48 $(0.04) \mathrm{mg} /$ day in women $(P=0.06)$, whereas at study end, the dose was $0.37(0.01)$ and $0.44(0.02) \mathrm{mg} /$ day respectively $(P<0.01)$. IGF1 SDS increased from -1.30 (0.13) at baseline to $0.88(0.18)$ after 15 years of $\mathrm{GH}$ replacement in men and from $-1.89(0.15)$ to 0.53 (0.18) in women $(P<0.001$ men vs women). At baseline, women had a higher serum TC level $(6.3$ (1.4) vs $5.8(0.13) \mathrm{mmol} / \mathrm{l}, \mathrm{P}<0.05)$ and higher serum HDL-C level (1.4 (0.06) vs 1.1 (0.03) mmol/l, $P<0.001)$ than men. Similar differences in serum lipid profile were seen after 15 years of $\mathrm{GH}$ replacement (data not shown). In women, the decrease in serum LDL-C was marginally greater than that in men $(P<0.05$; data not shown). There was no gender difference in the treatment effect in terms of other

Table 3 The dose of GH during 15 years of GH replacement in 156 GHD adults and the effects of this treatment on serum IGF1 concentration, IGF1 SDS, height, weight, BMI, and blood pressure. All values are shown as the mean (S.E.M.).

\begin{tabular}{|c|c|c|c|c|c|c|c|c|c|}
\hline & $\begin{array}{l}\text { Baseline } \\
(n=156)\end{array}$ & $\begin{array}{c}1 \text { year } \\
(n=154)\end{array}$ & $\begin{array}{c}3 \text { years } \\
(n=146)\end{array}$ & $\begin{array}{c}5 \text { years } \\
(n=136)\end{array}$ & $\begin{array}{l}7 \text { years } \\
(n=135)\end{array}$ & $\begin{array}{l}10 \text { years } \\
(n=125)\end{array}$ & $\begin{array}{l}12 \text { years } \\
(n=117)\end{array}$ & $\begin{array}{l}15 \text { years } \\
(n=109)\end{array}$ & $\begin{array}{c}\boldsymbol{P} \text { value } \\
\text { (10-15 } \\
\text { years) }\end{array}$ \\
\hline $\begin{array}{l}\text { Dose of GH } \\
\text { (mg/day) }\end{array}$ & $0.55(0.03)$ & $0.56(0.02)$ & $0.56(0.02)^{\ddagger}$ & $\ddagger 0.47(0.02)^{\ddagger}$ & $\ddagger 0.44(0.01)^{\ddagger}$ & $0.42(0.01)^{\ddagger}$ & $\ddagger 0.41(0.01)^{\ddagger}$ & ${ }^{\ddagger} 0.40(0.01)^{\ddagger}$ & $<0.001$ \\
\hline Serum IGF1 $(\mu \mathrm{g} / \mathrm{l})$ & $109(5)$ & $307(10)^{\ddagger}$ & $294(9)^{\ddagger}$ & $269(9)^{\ddagger}$ & $241(8)^{\ddagger}$ & $204(7)^{\ddagger}$ & $185(7)^{\ddagger}$ & $183(7)^{\ddagger}$ & $<0.001$ \\
\hline IGF1 SDS & $-1.53(0.10)$ & $2.49(0.21)^{\ddagger}$ & $\mp 2.32(0.17)^{\ddagger}$ & $\ddagger 1.91(0.17)^{\ddagger}$ & $\neq 1.48(0.15)^{\ddagger}$ & $0.89(0.19)^{\ddagger}$ & $\neq 0.61(0.13)^{\ddagger}$ & ${ }^{\ddagger} 0.74(0.13)^{\ddagger}$ & NS \\
\hline Height $(\mathrm{cm})$ & $172.3(0.8)$ & $172.6(0.8)$ & $172.6(0.8)$ & $172.4(0.8)$ & $172.1(0.8)$ & $171.7(0.8)$ & $171.6(0.9)$ & $171.5(0.9)$ & NS \\
\hline Weight (kg) & 82.5 (1.3) & 82.0 & $82.8(1.3)$ & $83.1(1.3)$ & $83.7(1.3)$ & $83.3(1.3)$ & $83.3(1.3)$ & $83.5(1.3)$ & NS \\
\hline BMI $\left(\mathrm{kg} / \mathrm{m}^{2}\right)$ & $27.7(0.4)$ & $27.5(0.4)$ & $27.7(0.4)$ & $27.9(0.4)$ & $28.2(0.38)^{*}$ & $28.2(0.4)^{*}$ & $28.2(0.4)^{\dagger}$ & $28.3(0.4)^{\dagger}$ & NS \\
\hline $\mathrm{SBP}(\mathrm{mmHg})$ & $123.4(1.3)$ & $122.2(1.3)$ & $125.3(1.4)$ & $124.5(1.3)$ & $127.1(1.4)$ & $130.5(1.5)^{\ddagger}$ & $131.7(1.5)^{\ddagger}$ & $133.4(1.5)^{\ddagger}$ & $<0.05$ \\
\hline $\mathrm{DBP}(\mathrm{mmHg})$ & $78.0(0.9)$ & $75.4(0.9)$ & $76.1(0.8)$ & $75.4(0.9)$ & $76.0(0.8)$ & $77.5(0.8)$ & $79.4(0.8)$ & $79.3(0.8)$ & $<0.01$ \\
\hline
\end{tabular}

The statistical analyses are based on a one-way ANOVA followed by Student-Newman-Keuls post hoc test. $P$ values (10-15 years) are based on the statistical analysis between the 10- and 15-year values. ${ }^{\star} P<0.05,{ }^{\dagger} P<0.01$, and ${ }^{\ddagger} P<0.001$ (for the dose of GH vs initial GH dose; for other variables vs baseline). NS, non-significant; GHD, GH deficiency; SBP, systolic blood pressure; DBP, diastolic blood pressure; IGF1, insulin-like growth factor 1. 

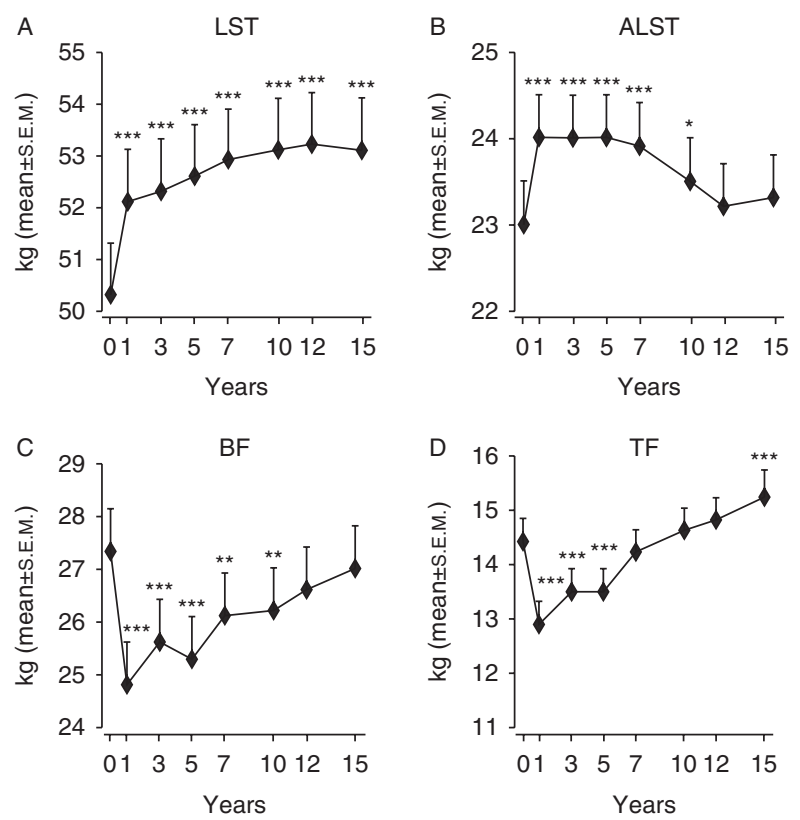

Figure 1 Effects of 15 years of $\mathrm{GH}$ replacement in 156 adults with adult-onset GHD on (A) LST, (B) ALST, (C) BF, and (D) TF as measured using dual-energy X-ray absorptiometry (DXA). All values are shown as the mean (s.E.M.). The statistical analyses are based on a repeated-measures ANOVA followed by StudentNewman-Keuls post hoc test. ${ }^{*} P<0.05$, ${ }^{\star *} P<0.01$, and

${ }^{* \star \star} P<0.001$ vs baseline. LST, lean soft tissue; ALST, appendicular lean soft tissue; BF, body fat; TF, trunk fat.

serum lipid levels, plasma glucose, blood HbA1c, blood pressure, or body composition (data not shown).

\section{Women on estrogen replacement vs women without estrogen replacement}

Of the 57 gonadotropin-deficient women, 34 (60\%) at study start and 15 (26\%) at study end received estrogen replacement therapy. The reason for fewer women receiving estrogen replacement at study end compared with baseline was discontinuation because of age. The women receiving estrogen replacement at baseline were younger (estrogen, mean age 45.3 (1.8) years vs not estrogen, 58.9 (2.0) years; $P<0.001)$. Women on estrogen replacement therapy received a higher dose of $\mathrm{GH}$ than women without estrogen replacement $(P<0.001)$. There was no difference in the baseline level or the treatment response in any variable studied between women with or without estrogen replacement at baseline.

\section{Discussion}

This single-center study is the longest and largest observational study of the effects of GH replacement on body composition and cardiovascular risk factors in patients with adult-onset GHD. The results demonstrate that 15 years of $\mathrm{GH}$ replacement induced a transient decrease in BF and sustained improvements of LST and serum lipid profile.

The first 64 patients initially received a weight-based dose of $\mathrm{GH}$, which was gradually lowered and individualized, whereas the remaining patients received individualized $\mathrm{GH}$ replacement from the beginning. This resulted in supraphysiological IGF1 SDS values during the first 3 years of treatment, but during the remaining part of the study, mean IGF1 SDS was within the normal range $( \pm 2$ s.D.). The 15 years of $\mathrm{GH}$ replacement increased BMI as observed in other studies $(8,9,10)$. This suggests that BMI increases during long-term GH replacement as in the general population during a 15-year period (25).

There was a sustained increase in total LST. By contrast, ALST, used as an estimate of skeletal muscle mass (20), returned to the baseline level after 10 years of $\mathrm{GH}$ replacement. This is in accordance with our previous results on muscle strength, which after an initial increase decreases with age as in the background population (26). Previous studies have shown a greater effect of GH on proximal compared with distal lean mass (27), which might be in line with our results of increased total LST but unchanged ALST after 15 years of GH replacement. However, whether the increase in proximal (mainly trunk) lean mass after 15 years represents increases in muscle tissue, visceral organs, and/or connective tissue cannot be determined using DXA.

During the first year of GH replacement, in line with the results of previous short-term studies $(4,6)$ and a recent meta-analysis (5), total body and TF decreased. After the initial decrease, total BF gradually returned to the baseline level, whereas TF was even above the baseline level at study end. This is in line with increased abdominal fat mass in relation to peripheral fat mass seen in normal aging (28). Although BF returned to the baseline level, total BF expressed as a percentage of body weight was still significantly below the baseline level at study end. This suggests that 15 years of $\mathrm{GH}$ replacement has, after correction for body weight, a sustained effect on the relative amount of BF.

Improvements in serum lipid profile, with increased HDL-C and decreased TC and LDL-C, were sustained. This is likely not explained by the transient improvements in body composition. Direct effects of GH on lipid metabolism are supported by previous studies. $\mathrm{GH}$ increases the expression of LDL receptors (29) and enhances the catabolism of LDL (30). GH administration may increase the turnover of LDL to a higher degree than indicated by changes seen in serum LDL-C concentrations (31), and GH increases very LDL-apolipoprotein B turnover (32). Furthermore, as we have previously observed (8), fasting blood glucose increased whereas blood HbA1c was reduced. Although the meaning of this finding is unclear, it could suggest that insulin sensitivity was approximately unchanged. 
Table 4 Effects of 15 years of GH replacement in 156 adults with adult-onset GHD on body composition corrected for body weight, serum lipid profile, fasting plasma glucose, and blood HbA1c. All values are shown as the mean (S.E.M.).

\begin{tabular}{|c|c|c|c|c|c|c|c|c|c|}
\hline & $\begin{array}{l}\text { Baseline } \\
(n=156)\end{array}$ & $\begin{array}{c}1 \text { year } \\
(n=154)\end{array}$ & $\begin{array}{l}3 \text { years } \\
(n=146)\end{array}$ & $\begin{array}{l}5 \text { years } \\
(n=136)\end{array}$ & $\begin{array}{l}7 \text { years } \\
(n=135)\end{array}$ & $\begin{array}{l}10 \text { years } \\
(n=125)\end{array}$ & $\begin{array}{l}12 \text { years } \\
(n=117)\end{array}$ & $\begin{array}{l}15 \text { years } \\
(n=109)\end{array}$ & $\begin{array}{c}\boldsymbol{P} \text { value } \\
\text { (10-15 } \\
\text { years) }\end{array}$ \\
\hline \multicolumn{10}{|l|}{ Body composition } \\
\hline LST/weight (\%) & $62.2(0.7)$ & $65.2(0.8)^{\star \star \star}$ & $64.6(0.8)^{\star \star \star}$ & $64.8(0.8)^{\star \star \star}$ & $64.5(0.8)^{\star \star \star}$ & $64.3(0.8)^{\star \star \star}$ & $64.2(0.8)^{\star \star \star}$ & $63.7(0.8)^{\star \star \star}$ & $<0.01$ \\
\hline ALST/weight (\%) & $28.3(0.4)$ & $29.8(0.4)^{\star \star \star}$ & $29.5(0.4)^{\star \star \star}$ & $29.5(0.4)^{\star \star \star}$ & $29.2(0.4)^{\star \star \star}$ & $28.8(0.4)^{\star \star \star}$ & $28.6(0.4)$ & $28.5(0.4)$ & $<0.01$ \\
\hline BF/weight (\%) & $33.7(0.8)$ & $30.9(0.8)^{\star \star \star}$ & $31.5(0.8)^{\star \star \star}$ & $31.0(0.8)^{\star \star \star}$ & $31.7(0.8)^{\star \star \star}$ & $32.0(0.8)^{\star \star \star}$ & $32.3(0.8)^{\star \star \star}$ & $32.7(0.8)^{\star *}$ & $<0.001$ \\
\hline TF/weight (\%) & $20.7(0.4)$ & $18.9(0.4)^{\star \star \star}$ & $19.3(0.5)^{\star \star \star}$ & $19.5(0.6)^{\star * \star}$ & $20.2(0.5)^{\star}$ & $20.5(0.6)$ & $20.5(0.6)$ & $21.2(0.7)^{\star *}$ & $<0.001$ \\
\hline \multicolumn{10}{|l|}{ Serum lipids } \\
\hline $\mathrm{TC}(\mathrm{mmol} / \mathrm{l})$ & $6.0(0.1)$ & $5.8(0.1)^{\star}$ & $5.7(0.1)^{\star \star \star}$ & $5.5(0.1)^{\star \star \star}$ & $5.5(0.1)^{\star \star \star}$ & $5.4(0.1)^{\star \star \star}$ & $5.4(0.1)^{\star \star \star}$ & $5.5(0.1)^{\star \star \star}$ & NS \\
\hline LDL-C (mmol/l) & $4.0(0.1)$ & $3.7(0.1)^{\star \star \star}$ & $3.6(0.1)^{\star \star \star}$ & $3.4(0.1)^{\star \star \star}$ & $3.4(0.1)^{\star \star \star}$ & $3.3(0.1)^{\star \star \star}$ & $3.2(0.1)^{\star \star \star}$ & $3.3(0.1)^{\star \star \star}$ & NS \\
\hline HDL-C (mmol/li) & $1.2(0.03)$ & $1.3(0.03)$ & $1.3(0.03)^{\star}$ & $1.3(0.03)^{\star}$ & $1.3(0.03)^{\star}$ & $1.4(0.07)^{\star \star \star}$ & * $1.4(0.04)^{\star \star \star}$ & * $1.4(0.04)^{\star \star \star}$ & NS \\
\hline $\mathrm{TG}(\mathrm{mmol} / \mathrm{l})$ & $1.7(0.1)$ & $1.8(0.1)$ & $1.7(0.1)$ & $1.7(0.1)$ & $1.7(0.1)$ & $1.8(0.1)$ & $1.8(0.1)$ & $1.8(0.1)$ & NS \\
\hline \multicolumn{10}{|l|}{$\begin{array}{l}\text { Glucose } \\
\text { metabolism }\end{array}$} \\
\hline Glucose $(\mathrm{mmol} / \mathrm{l})$ & $4.4(0.05)$ & $4.7(0.05)^{\star \star \star \star}$ & $4.6(0.05)^{\star \star}$ & $4.6(0.05)^{\star \star}$ & * $4.7(0.06)^{\star \star \star}$ & * $4.8(0.06)^{\star \star * *}$ & * $4.8(0.05)^{\star * *}$ & * $4.8(0.06)^{\star * *}$ & NS \\
\hline $\mathrm{HbA} 1 \mathrm{c}(\%)$ & $5.0(0.04)$ & $5.0(0.05)$ & $4.9(0.05)$ & $4.8(0.05)$ & $4.7(0.06)^{\star \star \star *}$ & * $4.6(0.07)^{\star \star \star *}$ & * $4.6(0.06)^{\star \star \star *}$ & * $4.6(0.06)^{\star \star \star *}$ & NS \\
\hline
\end{tabular}

The statistical analyses are based on a repeated-measures ANOVA followed by Student-Newman-Keuls post hoc test. $P$ values (10-15 years) are based on the statistical analysis between the 10- and 15-year values. GHD, GH deficiency; TC, total cholesterol; LDL-C, LDL-cholesterol; HDL-C, HDL-cholesterol; TGs, triglycerides; LST/weight, lean soft tissue as a percentage of body weight; ALST/weight, appendicular lean soft tissue as a percentage of body weight; $\mathrm{BF} /$ weight, body fat as a percentage of body weight; TF/weight, trunk fat as percentage of body weight.

${ }^{\star} P<0.05,{ }^{* \star} P<0.01,{ }^{* \star *} P<0.001$ vs baseline

In further support of unchanged insulin sensitivity, serum TG level, which is inversely correlated with insulin sensitivity (31), was unchanged.

At baseline, four patients had DM type 2. GHD adults not receiving GH replacement are insulin resistant $(33,34)$ and may therefore be at increased risk of developing DM type 2. In two recently published studies based on international surveillance databases, patients with obesity and disturbed metabolic profile at baseline were at increased risk of diabetes $(35,36)$. One of the studies showed a higher overall risk of diabetes, in particular during the first year of GH replacement (36), and the other study showed a diabetes incidence that was similar or slightly increased compared with the background population (35). In our study, in which most patients received a low dose of GH at initiation of therapy, only two patients developed DM type 2 during the first 5 years of GH replacement. However, another nine patients developed DM type 2 during the remaining study period, suggesting that a proportion of GHD patients will develop DM type 2 with increasing duration of GH replacement and increasing age of the patients. In line with the results of the aforementioned studies $(35,36)$, the patients who developed DM type 2 were more obese and had more disturbed glucose at baseline. In a general population in Sweden aged 20-100 years, the incidence of DM type 2 was 378 cases per 100000 and year (37). With this incidence, eight GHD patients would be expected to develop DM type 2, which indicates an increased risk in our patients compared with the normal population. Furthermore, in a Swedish multi-center study, the prevalence of diabetes was increased in GHD women but not in GHD men on $\mathrm{GH}$ replacement, partly attributed to reduced physical activity and increased BMI in the GHD women (38). Therefore, whether increased risk of DM type 2 in adult GHD is due to impaired metabolic baseline status and sedentary life-style or whether the risk is accelerated by $\mathrm{GH}$ replacement needs to be determined in more detail in further studies.

During the study period, 21 patients died, equivalent to one death in 94 patient years. In one study from our center, there was one death in 180 patient years (39). One study based on the global KIMS database and one Dutch national study has observed a mortality rate of one death per 130-140 patient years, which was slightly higher than that expected in the background population $(40,41)$. Thus, the mortality rate was higher in this study but the patients were older at baseline and the mean follow-up time in the other studies was shorter, 4-6 years $(39,40,41)$. Furthermore, whether the improvements in cardiovascular risk factors seen during the 15 years of GH replacement will result in reduced mortality from cardiovascular diseases (CVD) remain to be proven. In previous studies of hypopituitary patients not receiving $\mathrm{GH}$ replacement, all-cause mortality was almost doubled compared with that of the general population, mainly due to increased CVD mortality $(2,3)$. The mortality in hypopituitary patients receiving GH replacement in the Dutch national study and the KIMS study was 27 and 13\% respectively higher than that of the background population $(40,41)$. CVD mortality remained increased in women in the Dutch national study $(40,41)$ whereas in the KIMS study, cerebrovascular but not cardiovascular mortality was increased $(40,41)$. Taken together, this could indicate that the beneficial effects of $\mathrm{GH}$ replacement on cardiovascular risk factors might 
reduce CVD mortality, although all-cause mortality could still be increased compared with that in the general population. However, larger studies are needed to determine in more detail whether GH replacement can reduce the increased overall and cardiovascular mortality seen in untreated GHD.

Sixty $(38 \%)$ of our patients had received pituitary irradiation therapy (combined surgery and radiotherapy, $n=47$, and radiotherapy alone, $n=13$ ), and 96 $(62 \%)$ of our patients had not received radiotherapy. Thirteen $(62 \%)$ of the 21 patients who died during the study period had previously received radiotherapy and five $(42 \%)$ of the 12 patients who developed DM type 2 during the study period had previously received radiotherapy. Although the importance of previous radiotherapy needs to be evaluated in larger studies than the present one, these data might suggest that previous radiotherapy is a risk factor for increased mortality in hypopituitary patients whereas previous radiotherapy does not appear to be a major determinant of the risk of DM type 2 during GH replacement therapy.

Women received, in line with previous studies $(8,9,42)$, a higher GH dose than men. Except for a marginally more beneficial reduction of serum LDL-C level in women, there were no gender differences in the treatment responses in any variables reflecting body composition or metabolic indices. This suggests similar responsiveness to long-term GH replacement in these variables if women receive a higher dose of $\mathrm{GH}$ than men. Gonadotropin-deficient women on estrogen replacement received a higher $\mathrm{GH}$ dose compared with those not receiving estrogen. However, the treatment response was similar in the two groups.

A limitation of the study is that there was no untreated control group. Furthermore, at the end of 1999, the DXA machine used was changed. The new DXA was, however, found to give similar estimates of body composition parameters as the old one. Finally, the assays for measurements of glucose and IGF1 were changed during the study period. Based on measurements in the local laboratory, a conversion factor of 1.11 was used to transfer blood glucose values to plasma glucose values. In terms of the IGF1 measurements, the WHO NIBSC 1st IRR 87/518 standard was used for calibration throughout the study period.

In conclusion, 15 years of $\mathrm{GH}$ replacement in hypopituitary adults resulted in a sustained increase in LST whereas most other changes in body composition were transient, possibly at least to some extent due to the normal aging of the patients. The improvements in lipid profile were sustained and taking into consideration the relatively small changes in body composition at study end, this indicates direct GH effects on lipid metabolism. The effects on glucose metabolism were conflicting, but possibly, glucose homeostasis was approximately unchanged. The risk of DM type 2 is, however, probably increased in obese GHD adults with impaired glucose homeostasis at baseline. Future larger studies are needed to investigate whether the increased mortality seen in hypopituitary adults not receiving $\mathrm{GH}$ $(2,3)$ can be affected by GH replacement.

\section{Declaration of interest}

G Johannsson has received lecture fees from Pfizer, Novo Nordisk, Merck Serono, and Eli Lilly and is a member of the SAB for KIMS Pfizer. B- $\AA$ Bengtsson has previously received a research grant from Pharmacia/Pfizer. All other authors declare that there is no conflict of interest that could be perceived as prejudicing the impartiality of the research reported.

\section{Funding}

The study received support from the Swedish Research Council (grant 523-2007-7111), the Region of Västra Götaland and the Sahlgrenska Academy research grants (grants ALFGBG-146841 and ALFGBG151151), and unrestricted research grants from Novo Nordisk and Pfizer. The authors are indebted to all the staff at the Department of Endocrinology for their skillful technical support.

\section{References}

1 de Boer H, Blok GJ \& Van der Veen EA. Clinical aspects of growth hormone deficiency in adults. Endocrine Reviews 199516 63-86. (doi:10.1210/er.16.1.63)

2 Rosen T \& Bengtsson BA. Premature mortality due to cardiovascular disease in hypopituitarism. Lancet 1990336 285-288. (doi:10.1016/0140-6736(90)91812-O)

3 Tomlinson JW, Holden N, Hills RK, Wheatley K, Clayton RN, Bates AS, Sheppard MC \& Stewart PM. Association between premature mortality and hypopituitarism. West Midlands Prospective Hypopituitary Study Group. Lancet 2001357 425-431. (doi:10.1016/S0140-6736(00)04006-X)

4 Boguszewski CL, Meister LH, Zaninelli DC \& Radominski RB. One year of GH replacement therapy with a fixed low-dose regimen improves body composition, bone mineral density and lipid profile of GH-deficient adults. European Journal of Endocrinology 2005152 67-75. (doi:10.1530/eje.1.01817)

5 Hazem A, Elamin MB, Bancos I, Malaga G, Prutsky G, Domecq JP, Elraiyah TA, Abu Elnour NO, Prevost Y, Almandoz JP et al. Therapy in endocrine disease: body composition and quality of life in adults treated with GH therapy: a systematic review and meta-analysis. European Journal of Endocrinology 2012166 13-20. (doi:10.1530/ EJE-11-0558)

6 Hoffman AR, Kuntze JE, Baptista J, Baum HB, Baumann GP, Biller BM, Clark RV, Cook D, Inzucchi SE, Kleinberg D et al. Growth hormone $(\mathrm{GH})$ replacement therapy in adult-onset $\mathrm{GH}$ deficiency: effects on body composition in men and women in a double-blind, randomized, placebo-controlled trial. Journal of Clinical Endocrinology and Metabolism 200489 2048-2056. (doi:10.1210/jc. 2003-030346)

7 Gibney J, Wallace JD, Spinks T, Schnorr L, Ranicar A, Cuneo RC, Lockhart S, Burnand KG, Salomon F, Sonksen PH et al. The effects of 10 years of recombinant human growth hormone $(\mathrm{GH})$ in adult GH-deficient patients. Journal of Clinical Endocrinology and Metabolism $1999842596-2602$. (doi:10.1210/jc.84.8.2596)

8 Gotherstrom G, Bengtsson BA, Bosaeus I, Johannsson G \& Svensson J. A 10-year, prospective study of the metabolic effects of growth hormone replacement in adults. Journal of Clinical Endocrinology and Metabolism 200792 1442-1445. (doi:10.1210/jc. 2006-1487)

9 van der Klaauw AA, Romijn JA, Biermasz NR, Smit JW, van Doorn J, Dekkers OM, Roelfsema F \& Pereira AM. Sustained effects 
of recombinant $\mathrm{GH}$ replacement after 7 years of treatment in adults with GH deficiency. European Journal of Endocrinology 2006 155 701-708. (doi:10.1530/eje.1.02283)

10 Arwert LI, Roos JC, Lips P, Twisk JW, Manoliu RA \& Drent ML. Effects of 10 years of growth hormone (GH) replacement therapy in adult GH-deficient men. Clinical Endocrinology 2005 63 310-316. (doi:10.1111/j.1365-2265.2005.02343.x)

11 Fideleff HL, Boquete HR, Stalldecker G, Giaccio AV \& Sobrado PG. Comparative results of a 4-year study on cardiovascular parameters, lipid metabolism, body composition and bone mass between untreated and treated adult growth hormone deficient patients. Growth Hormone \& IGF Research 200818 318-324. (doi:10.1016/j.ghir.2008.01.002)

12 Svensson J, Fowelin J, Landin K, Bengtsson BA \& Johansson JO. Effects of seven years of GH-replacement therapy on insulin sensitivity in GH-deficient adults. Journal of Clinical Endocrinology and Metabolism 200287 2121-2127. (doi:10.1210/jc.87.5. 2121)

13 Rosenfalck AM, Maghsoudi S, Fisker S, Jorgensen JO, Christiansen JS, Hilsted J, Volund AA \& Madsbad S. The effect of 30 months of low-dose replacement therapy with recombinant human growth hormone (rhGH) on insulin and C-peptide kinetics, insulin secretion, insulin sensitivity, glucose effectiveness, and body composition in GH-deficient adults. Journal of Clinical Endocrinology and Metabolism 200085 4173-4181. (doi:10.1210/jc.85.11.4173)

14 Giavoli C, Porretti S, Ronchi CL, Cappiello V, Ferrante E, Orsi E, Arosio M \& Beck-Peccoz P. Long-term monitoring of insulin sensitivity in growth hormone-deficient adults on substitutive recombinant human growth hormone therapy. Metabolism: Clinical and Experimental 200453 740-743. (doi:10.1016/j. metabol.2003.11.025)

15 Hwu CM, Kwok CF, Lai TY, Shih KC, Lee TS, Hsiao LC, Lee SH, Fang VS \& Ho LT. Growth hormone (GH) replacement reduces total body fat and normalizes insulin sensitivity in GH-deficient adults: a report of one-year clinical experience. Journal of Clinical Endocrinology and Metabolism 199782 3285-3292. (doi:10.1210/jc.82.10.3285)

16 Yuen KC, Frystyk J, White DK, Twickler TB, Koppeschaar HP, Harris PE, Fryklund L, Murgatroyd PR \& Dunger DB. Improvement in insulin sensitivity without concomitant changes in body composition and cardiovascular risk markers following fixed administration of a very low growth hormone $(\mathrm{GH})$ dose in adults with severe GH deficiency. Clinical Endocrinology 200563 428-436. (doi:10.1111/j.1365-2265.2005.02359.x)

17 Elbornsson M, Gotherstrom G, Bosaeus I, Bengtsson BA, Johannsson G \& Svensson J. Fifteen years of GH replacement increases bone mineral density in hypopituitary patients with adult-onset GH deficiency. European Journal of Endocrinology 2012 166 787-795. (doi:10.1530/EJE-11-1072)

18 Johannsson G, Rosen T \& Bengtsson BA. Individualized dose titration of growth hormone $(\mathrm{GH})$ during $\mathrm{GH}$ replacement in hypopituitary adults. Clinical Endocrinology 1997 47 571-581. (doi:10.1046/j.1365-2265.1997.3271123.x)

19 Mazess RB, Barden HS, Bisek JP \& Hanson J. Dual-energy X-ray absorptiometry for total-body and regional bone-mineral and softtissue composition. American Journal of Clinical Nutrition $1990 \mathbf{5 1}$ 1106-1112.

20 Kim J, Shen W, Gallagher D, Jones A Jr, Wang Z, Wang J, Heshka S \& Heymsfield SB. Total-body skeletal muscle mass: estimation by dual-energy X-ray absorptiometry in children and adolescents. American Journal of Clinical Nutrition 200684 1014-1020.

21 Brabant G, von zur Muhlen A, Wuster C, Ranke MB, Kratzsch J, Kiess W, Ketelslegers JM, Wilhelmsen L, Hulthen L, Saller B et al. Serum insulin-like growth factor I reference values for an automated chemiluminescence immunoassay system: results from a multicenter study. Hormone Research 200360 53-60. (doi:10.1159/000071871)

22 Landin-Wilhelmsen K, Wilhelmsen L, Lappas G, Rosen T, Lindstedt G, Lundberg PA \& Bengtsson BA. Serum insulin-like growth factor I in a random population sample of men and women: relation to age, sex, smoking habits, coffee consumption and physical activity, blood pressure and concentrations of plasma lipids, fibrinogen, parathyroid hormone and osteocalcin. Clinical Endocrinology $1994 \mathbf{4 1}$ 351-357. (doi:10.1111/j.1365-2265. 1994.tb02556.x)

23 Svensson J, Johannsson G \& Bengtsson BA. Insulin-like growth factor-I in growth hormone-deficient adults: relationship to population-based normal values, body composition and insulin tolerance test. Clinical Endocrinology 199746 579-586. (doi:10.1046/j.1365-2265.1997.1851001.x)

24 Friedewald WT, Levy RI \& Fredrickson DS. Estimation of the concentration of low-density lipoprotein cholesterol in plasma, without use of the preparative ultracentrifuge. Clinical Chemistry 197218 499-502.

25 Berg C, Rosengren A, Aires N, Lappas G, Toren K, Thelle D \& Lissner L. Trends in overweight and obesity from 1985 to 2002 in Goteborg, West Sweden. International Journal of Obesity 2005 29 916-924. (doi:10.1038/sj.ijo.0802964)

26 Gotherstrom G, Elbornsson M, Stibrant-Sunnerhagen K, Bengtsson BA, Johannsson G \& Svensson J. Ten years of growth hormone $(\mathrm{GH})$ replacement normalizes muscle strength in GH-deficient adults. Journal of Clinical Endocrinology and Metabolism 200994 809-816. (doi:10.1210/jc.2008-1538)

27 Lonn L, Johansson G, Sjostrom L, Kvist H, Oden A \& Bengtsson BA. Body composition and tissue distributions in growth hormone deficient adults before and after growth hormone treatment. Obesity Research 19964 45-54. (doi:10.1002/j.1550-8528. 1996.tb00511.x)

28 Christou DD, Jones PP, Pimentel AE \& Seals DR. Increased abdominal-to-peripheral fat distribution contributes to altered autonomic-circulatory control with human aging. American Journal of Physiology. Heart and Circulatory Physiology 2004287 H1530-H1537. (doi:10.1152/ajpheart.00322.2004)

29 Rudling M, Norstedt G, Olivecrona H, Reihner E, Gustafsson JA \& Angelin B. Importance of growth hormone for the induction of hepatic low density lipoprotein receptors. PNAS $1992 \mathbf{8 9}$ 6983-6987. (doi:10.1073/pnas.89.15.6983)

30 Christ ER, Cummings MH, Jackson N, Stolinski M, Lumb PJ, Wierzbicki AS, Sonksen PH, Russell-Jones DL \& Umpleby AM. Effects of growth hormone (GH) replacement therapy on lowdensity lipoprotein apolipoprotein B100 kinetics in adult patients with GH deficiency: a stable isotope study. Journal of Clinical Endocrinology and Metabolism 200489 1801-1807. (doi:10.1210/jc.2003-031474)

31 Angelin B \& Rudling M. Growth hormone and hepatic lipoprotein metabolism. Current Opinion in Lipidology 19945 160-165. (doi:10.1097/00041433-199405030-00002)

32 Christ ER, Cummings MH, Albany E, Umpleby AM, Lumb PJ, Wierzbicki AS, Naoumova RP, Boroujerdi MA, Sonksen PH \& Russell-Jones DL. Effects of growth hormone (GH) replacement therapy on very low density lipoprotein apolipoprotein B100 kinetics in patients with adult GH deficiency: a stable isotope study. Journal of Clinical Endocrinology and Metabolism $1999 \mathbf{8 4}$ 307-316. (doi:10.1210/jc.84.1.307)

33 Carroll PV, Christ ER, Bengtsson BA, Carlsson L, Christiansen JS, Clemmons D, Hintz R, Ho K, Laron Z, Sizonenko P et al. Growth hormone deficiency in adulthood and the effects of growth hormone replacement: a review. Growth Hormone Research Society Scientific Committee. Journal of Clinical Endocrinology and Metabolism 199883 382-395. (doi:10.1210/jc.83.2.382)

34 Johansson JO, Fowelin J, Landin K, Lager I \& Bengtsson BA. Growth hormone-deficient adults are insulin-resistant. Metabolism: Clinical and Experimental 199544 1126-1129. (doi:10.1016/00260495(95)90004-7)

35 Attanasio AF, Jung H, Mo D, Chanson P, Bouillon R, Ho KK, Lamberts SW, Clemmons DR \& Hypo CCSIAB. Prevalence and incidence of diabetes mellitus in adult patients on growth hormone replacement for growth hormone deficiency: a surveillance database analysis. Journal of Clinical Endocrinology and Metabolism 201196 2255-2261. (doi:10.1210/jc.2011-0448) 
36 Luger A, Mattsson AF, Koltowska-Haggstrom M, Thunander M, Goth M, Verhelst J \& Abs R. Incidence of diabetes mellitus and evolution of glucose parameters in growth hormone-deficient subjects during growth hormone replacement therapy: a long-term observational study. Diabetes Care 201235 57-62. (doi:10.2337/dc11-0449)

37 Thunander M, Petersson C, Jonzon K, Fornander J, Ossiansson B, Torn C, Edvardsson S \& Landin-Olsson M. Incidence of type 1 and type 2 diabetes in adults and children in Kronoberg, Sweden. Diabetes Research and Clinical Practice $2008 \quad 82$ 247-255. (doi:10.1016/j.diabres.2008.07.022)

38 Holmer H, Svensson J, Rylander L, Johannsson G, Rosen T, Bengtsson BA, Thoren M, Hoybye C, Degerblad M, Bramnert M et al. Nonfatal stroke, cardiac disease, and diabetes mellitus in hypopituitary patients on hormone replacement including growth hormone. Journal of Clinical Endocrinology and Metabolism 2007 92 3560-3567. (doi:10.1210/jc.2007-0458)

39 Svensson J, Bengtsson BA, Rosen T, Oden A \& Johannsson G. Malignant disease and cardiovascular morbidity in hypopituitary adults with or without growth hormone replacement therapy. Journal of Clinical Endocrinology and Metabolism $2004 \mathbf{8 9}$ 3306-3312. (doi:10.1210/jc.2003-031601)

40 Gaillard RC, Mattsson AF, Akerblad AC, Bengtsson BA, Cara J, Feldt-Rasmussen U, Koltowska-Haggstrom M, Monson JP, Saller B,
Wilton P et al. Overall and cause-specific mortality in GH-deficient adults on GH replacement. European Journal of Endocrinology 2012 166 1069-1077. (doi:10.1530/EJE-11-1028)

41 van Bunderen CC, van Nieuwpoort IC, Arwert LI, Heymans MW, Franken AA, Koppeschaar HP, van der Lely AJ \& Drent ML. Does growth hormone replacement therapy reduce mortality in adults with growth hormone deficiency? Data from the Dutch National Registry of Growth Hormone Treatment in adults. Journal of Clinical Endocrinology and Metabolism 201196 3151-3159. (doi:10.1210/jc.2011-1215)

42 Jorgensen AP, Fougner KJ, Ueland T, Gudmundsen O, Burman P, Schreiner T \& Bollerslev J. Favorable long-term effects of growth hormone replacement therapy on quality of life, bone metabolism, body composition and lipid levels in patients with adult-onset growth hormone deficiency. Growth Hormone \& IGF Research 2011 21 69-75. (doi:10.1016/j.ghir.2011.01.001)

Received 15 December 2012

Revised version received 9 February 2013

Accepted 21 February 2013 